\title{
Partiskiftere og politik som oplevelse
}

\section{Af Johannes Andersen}

Partiskiftere bliver et mere og mere centralt element $i$ den moderne politiske kultur, og som sådan er de medvirkende til at give de politiske processer dynamik og udfordringer. Derfor står de centralt $i$ alle politiske partiers sigtekorn, når man narmer sig eksempelvis et folketingsvalg. Det er ikke mindst de unge, der indtager rollen som partiskifter. De orienterer sig i forhold til det politiske isar i forbindelse med valgkampe, og de afgør ofte, hvor de skal stemme, i løbet af valgkampens sidste dage. Her er de ikke mindst parvirket af de politiske lederes aktiviteter. Det kan meget vel betyde, at den politiske kommunikation $i$ stigende udstrakning kommer til at indeholde oplevelsesbaserede elementer på bekostning af mere holdningsprofilerede positioner. Artiklen omhandler således en rakke centrale vilkår for den type politisk kommunikation, der analyseres i efterfolgende artikler.

\section{Partiskiftere}

Set fra politikernes synsvinkel er der ingen tvivl om, at vælgere, der skifter parti fra det ene valg til det næste, er en stor kvalitet i et moderne politisk system. De gør det nemlig muligt at vinde et valg, hvis man er i stand til at trække tilstrækkeligt mange vælgere over på sin side. Men det betyder samtidig, at de også er en konstant udfordring, for andre partier og politikere har jo den samme mulighed. Partiskiftere er med andre ord væsentlige ingredienser i både sejr og nederlag i forbindelse med eksempelvis et folketingsvalg. I det følgende vil jeg forsøge at lave en kortlægning af nogle af de elementer, der kendetegner partiskifterne.

En partiskifter kan defineres som en vælger, der ved et givet demokratisk valg stemmer på et andet parti end det, vedkommende stemte på sidst. Der er altså tale om en rolle, der er knyttet til et givet demokratisk valg, hvor det er muligt at vælge mellem forskellige politiske partier. En vælger, der er partiskifter ved folketingsvalget i 2005, er altså en vælger, der i 2005 stemte på et andet parti end vedkommende stemte på ved folketingsvalget i 2001. Om vedkommende så tidligere har været en meget trofast vælger, siger denne definition intet om. Det at være partiskifter afgøres ud fra en afgrænset tidshorisont, omfattende to valg.

Generelt er det danske politiske system ikke helt så dynamisk som eksempelvis det norske og det svenske, hvor andelen af partiskiftere gennem de seneste valg har været stærkt stigende, samti- dig med at valgdeltagelsen har været faldende. I Danmark har andelen af partiskiftere ved valgene i 1998 og 2001 ligget omkring 33 pct., mens stemmeprocenten har ligget på det samme stabile niveau. Ved valget i 2005 faldt andelen af partiskiftere til omkring 25 pct. (Møller Hansen et al, 2007: 68f). Der foreligger endnu ikke præcise data for folketingsvalget i 2007, men de foreløbige data viser, at niveauet igen er oppe omkring 33 pct. af vælgerne.

\section{En analysestrategi}

Der kan være forskellige grunde til, at man skifter parti. Det kan hænge sammen med strukturelle faktorer i det politiske system, og det kan hænge sammen med individuelle faktorer. Fremkomsten af et nyt politisk parti kan opfattes som en strukturel faktor. Det var tilfældet i 1973, hvor Mogens Glistrup og Fremskridtspartiet vendte op og ned på det danske politiske system. Her skiftede 44 pct. af vælgerne parti (Nielsen \& Thomsen, 2003: 67f). Det var i princippet også tilfældet i 1998, hvor Dansk Folkeparti for første gang stillede op til et valg. Men her lå niveauet for partiskiftere omkring det normale, nemlig omkring hver tredje vælger. Pointen er, at nye partier kan åbne op for nye muligheder for vælgerne, og det kan være ensbetydende med dramatiske vælgervandringer.

De individuelle faktorer vedrører først og fremmest den enkelte vælgers forhold til det politiske liv. Her kan der peges på flere forskellige dimensioner 
(Møller Hansen et al., 2007: 67ff): a. vælgernes sociale baggrund, b. vælgernes politiske engagement $\mathrm{og}$ c. vælgernes politiske ståsted. Hvor pointen er, at givne sociale baggrundsfaktorer kan virke fremmende for partiskifte. Det samme kan siges om eksempelvis den politiske interesse. Når det drejer sig om politisk ståsted, er perspektivet lidt anderledes. Her er sagen nok den, at de vælgere, der konfronteres med udsigten til et særligt heldigt eller problematisk valg, set ud fra det parti, man normalt støtter, formodentlig nemt kan overtales til at ændre deres valg af parti. Ikke mindst af taktiske grunde. Endelig skal det med, at relationen mellem vælgere og politikere formidles gennem medier. Derfor kan man også have en antagelse om, at givne medievaner kan spille ind på ens stemmeafgivning.

Den følgende undersøgelse sætter fokus på de individuelle faktorer. Først og fremmest fordi de strukturelle faktorer ikke spillede nogen rolle i forbindelse med folketingsvalget i 2005. I maj 2007 opstod partiet Ny Alliance, og det startede ifølge meningsmålingerne med en relativt god opbakning hos vælgerne. Mindst 11 pct. af vælgerne tilkendegav, at de ville stemme på partiet, mens mindst lige så mange overvejede det. Folketingsvalget den 13. november 2007 viste imidlertid, at partiet havde mistet en stor del af støtterne. Kun 2,8 pct. stemte på partiet, og det betyder, at partiets strukturelle effekt er begrænset. Desværre er der endnu ikke (februar 2008) tilgængelige data for folketingsvalget 2007, så de følgende beregninger er udelukkende baseret på data fra folketingsvalget i 2005. Der er imidlertid ikke grund til at forvente, at data fra 2007 ændrer grundlæggende på perspektiverne, når det drejer sig om partiskiftere.

Målet for denne undersøgelse er i første omgang at lokalisere de centrale kendetegn hos partiskifterne i 2005. Herunder deres interesse for politik, viden om politik og deres medievaner. Det er en kortlægning baseret på svar fra et repræsentativt udsnit af befolkningen, indsamlet i forbindelse med Det danske valgforskningsprojekts undersøgelse af valget 2005. Dernæst er det ambitionen at identificere centrale og mere sammenhængende mønstre i den politiske kultur, der kendetegner partiskifterne i 2005. Her benyttes statistiske beregninger af forskellige variable, indsamlet i ovennævnte undersøgelse. Der er altså tale om et forsøg på at identificere centrale mønstre i den danske politiske kultur, der konkret spillede en vis rolle for udfaldet af folketingsvalget 2005. Disse mønstre bruges efterfølgende til en afsluttende diskussion om tendenser i moderne politisk kommunikation, set ud fra vælgernes synsvinkel.

Den grundlæggende antagelse er, at oplevelsesbaserede elementer kommer til at fylde mere og mere i den danske politiske kultur, ikke mindst hos de unge vælgere. Og det er denne antagelse, der især vil blive fokuseret på i det følgende.

\section{Partiskifterne ved folketingsvalget 2005}

Som det allerede er nævnt, skiftede 25 pct. af vælgerne parti ved folketingsvalget 2005, sammenholdt med folketingsvalget 2001. Generelt gælder det for partiskifterne i 2005, at næsten halvdelen af dem også skiftede parti ved det foregående valg. Når man først har skiftet parti, så er man med andre ord i stand til at gøre det igen ved det følgende valg (Møller Hansen et al., 2007: 70).

I tabel 1 er der lavet en oversigt over forskellige sociale og politiske faktorer, med henblik på at tegne en profil af partiskifterne ved folketingsvalget 2005. I tabellen kan man få et indtryk af de steder, hvor partiskiftere er over- og underrepræsenteret, set i forhold til landsgennemsnittet. Det første, der falder i øjnene, er, at der på dette område ikke er forskel på mænd og kvinder. Med hensyn til alder er det især de unge, der skifter parti. Da der relativt set også er mange unge, der har studentereksamen, er det heller ikke så overraskende, at personer med lang skolegang har større tendens til skifte parti end personer med kortere skolegang.

Når det drejer sig om det politiske engagement, er det især personer, der ikke er interesserede i politik, der holder fast ved det samme parti. Man skal altså være lidt interesseret i forhold til det politiske for at skifte parti. Det slår tydeligere igennem, når det drejer sig om at diskutere politik. Her er folk, der har diskuteret politik under valgkampen, overrepræsenteret hos partiskifterne. Man skal altså have et relativt aktivt forhold til politik for at skifte parti. Derimod skal man ikke nødvendigvis vide en masse om politik. Det fremgår også af tabel 1. Folk med et lavt vidensniveau er overrepræsenteret hos partiskifterne.

Det er ikke særligt overraskende, at det især er folk, der ikke er tilhængere af et bestemt parti, der har lettest ved at skifte til et nyt. Det er nok heller ikke så overraskende, at de politiske ledere spiller en vis rolle for partiskifterne, når disse skal afgøre, 
Tabel 1. Andel partiskiftere ved folketingsvalget 2005. Pct

\begin{tabular}{|c|c|c|}
\hline & $\begin{array}{c}\text { Andel } \\
\text { partiskiftere }\end{array}$ & $\mathbf{N}$ \\
\hline I alt & 25 & 473 \\
\hline \multicolumn{3}{|l|}{ 1. Sociale faktorer } \\
\hline \multicolumn{3}{|l|}{ Køn } \\
\hline Mænd & 24 & 257 \\
\hline Kvinder & 25 & 216 \\
\hline \multicolumn{3}{|l|}{ Alder - født: } \\
\hline 1975-88 & 36 & 69 \\
\hline $1960-74$ & 30 & 160 \\
\hline $1945-59$ & 24 & 135 \\
\hline $1030-44$ & 18 & 84 \\
\hline før 1930 & 15 & 25 \\
\hline \multicolumn{3}{|l|}{ Skolegang } \\
\hline Folkeskole, real og 10. klasse & 22 & 279 \\
\hline Studentereksamen & 30 & 194 \\
\hline \multicolumn{3}{|l|}{ 2. Politisk engagement } \\
\hline \multicolumn{3}{|l|}{ Politisk interesse } \\
\hline Meget og noget interesseret & 26 & 371 \\
\hline Lidt og slet ikke interesseret & 21 & 102 \\
\hline \multicolumn{3}{|l|}{ Diskuteret politik } \\
\hline Diskuteret & 26 & 416 \\
\hline Ikke diskuteret & 18 & 58 \\
\hline \multicolumn{3}{|l|}{ Viden om politik } \\
\hline Lavt vidensniveau (0-2 korrekte svar) & 28 & 90 \\
\hline Generelt vidensniveau (3-5 korrekte svar) & 26 & 289 \\
\hline Højt vidensniveau (6-7 korrekte svar) & 19 & 94 \\
\hline \multicolumn{3}{|l|}{ Partisympati } \\
\hline Stærk tilhænger af et parti & 9 & 52 \\
\hline Moderat tilhænger af et parti & 17 & 71 \\
\hline Ikke tilhænger af et parti & 39 & 350 \\
\hline \multicolumn{3}{|l|}{ Beslutning om stemmeafgivning ud fra } \\
\hline Politiske holdninger & 20 & 181 \\
\hline Partilederen betød også noget for mit partivalg & 28 & 292 \\
\hline
\end{tabular}




\begin{tabular}{|c|c|c|}
\hline \multicolumn{3}{|l|}{ Valgkampens betydning } \\
\hline Valgkampen afklarer de politiske synspunkter & 25 & 211 \\
\hline Valgkampen afklarer ikke de politiske synspunkter & 24 & 262 \\
\hline \multicolumn{3}{|l|}{ Beslutningstidspunkt } \\
\hline I de sidste dage før valget & 52 & 188 \\
\hline Tidligere i valgkampen & 40 & 124 \\
\hline Før valgkampen & 13 & 161 \\
\hline \multicolumn{3}{|l|}{ 3. Politisk ståsted } \\
\hline \multicolumn{3}{|l|}{ Partitilhørsforhold } \\
\hline Enhedslisten & 43 & 28 \\
\hline $\mathrm{SF}$ & 33 & 38 \\
\hline Socialdemokraterne & 19 & 97 \\
\hline Radikale Venstre & 44 & 77 \\
\hline Konservativt Folkeparti & 34 & 67 \\
\hline Venstre & 15 & 87 \\
\hline Dansk Folkeparti & 24 & 58 \\
\hline \multicolumn{3}{|l|}{ 4. Medieforbrug } \\
\hline \multicolumn{3}{|l|}{ Tv-forbrug } \\
\hline Dagligt & 23 & 253 \\
\hline Sjældnere & 27 & 220 \\
\hline \multicolumn{3}{|l|}{ Avis forbrug } \\
\hline Dagligt & 22 & 202 \\
\hline Sjældnere & 26 & 271 \\
\hline \multicolumn{3}{|l|}{ Internettet } \\
\hline Søgt internettet & 31 & 75 \\
\hline Ikke søgt internettet & 24 & 398 \\
\hline
\end{tabular}

Kilde: Data fra Folketingsvalget 2005, Aalborg Universitet.

hvor de skal sætte krydset. Endelig er det også i løbet af selve valgkampen, at partiskifterne overbevises om, at de skal stemme på et nyt parti.

Politisk set er partiskiftere underrepræsenteret hos Venstre og Socialdemokraterne, mens Dansk Folkeparti ligger tæt på gennemsnittet. Samtidig er de overrepræsenteret hos Det radikale Venstre, Enhedslisten, De konservative og SF. Det vil sige, at de to store partier, der kæmpede om regeringsmagten i 2005, ikke havde held med at mobilisere ret mange nye vælgere. Begge partier støttede sig især til deres kernevælgere. Derimod havde deres respektive støttepartier bedre held med at mobilisere nye vælgere.
Endelig viser opgørelsen, at når det drejer sig om medieforbrug, er det vælgere med et relativt lavt forbrug af TV og aviser, der skifter parti. Derimod er partiskiftere flittige til at bruge internettet, hvilket passer godt med, at det især er de unge, der skifter parti.

Ved de foregående valg, hvor der var flere partiskiftere på banen, var den sociale og politiske profil stort set som ovennævnte (Nielsen \& Thomsen, 2003: 62; Andersen, 1999: 74). De vælgere, der skifter parti, ligner altså nogenlunde hinanden fra valg til valg, uanset hvor mange der er. 


\section{Partiskift som ungdomskultur}

Hvis man forsøger at samle de mange kendetegn til et mere sammenhængende mønster, så viser det sig, at det at være partiskifter set ud fra et individuelt perspektiv især er en central del af de unges politiske kultur. Og her bestemmes de unge som personer, der er født i perioden 1974-88. De unge er i en vis udstrækning interesserede i politik, vil gerne diskutere politik, men ved ikke nødvendigvis ret meget om politik. De følger heller ikke systematisk med i politik gennem daglig orientering i tv og aviser (Andersen \& Kristensen, 2006). Det er altså ikke den informationsbaserede vej, deres engagement i politik bygger på. Derimod følger de med i valgkampen, og de unge er dem, der i størst udstrækning finder, at valgkampen har været med til afklare de politiske synspunkter. De går til valgkampen med en forventning om, at det er på den måde, de finder ud af, hvem de skal stemme på, og her er der altså ret mange, der finder ud af, at de bør stemme på et andet parti end det, de stemte på sidst (Andersen, 2001: 65f.; 1999: 74f).

Skal man sammenfatte dette billede, kan man sige, at de unge først og fremmest er opmarksomme i forhold til politik. Her er de ikke mindst optagede af de mange valgmuligheder, der gives. De orienterer sig om disse muligheder, når der er valgkamp, og de lader sig ofte inspirere af valgkampens aktiviteter, herunder partilederes bidrag, når de skal afgøre, hvor krydset skal sættes. En inspiration, de ofte sætter på spil i diskussioner med familie, venner og kolleger. Derfor er det også de unge, der har de færreste problemer med at krydse over midten i dansk politik, og eksempelvis stemme på et socialistisk parti ved det ene valg og et borgerligt ved det næste (Andersen, 2001; 2000: 208f).

De unges form for politisk engagement adskiller sig markant fra den mere traditionelle form for politisk engagement, baseret på en løbende interesse for politik og især på en grundlæggende sympati med et bestemt parti. Her ønsker man løbende at følge med i, hvordan ens parti klarer sig i det politiske magtspil, og derfor følger man også dagligt med i politik gennem tv, radio og aviser. Vidensniveauet er højt, og det med at diskutere med andre er noget, man gør, men det er ikke så udbredt som hos de unge. Man har som udgangspunkt nogle interesser, som man håber ens parti kan forsvare. Hvis man af en eller anden grund bliver utilfreds med dette forsvar, kan man overveje at stemme på et andet parti, der ofte ligger relativt tæt på. Men det er ikke nemt, fordi det kan opfattes som et svigt, og derfor sker det relativt sjældent. Her er der endvidere næsten ingen, der svinger over fra den ene blok til den anden. Denne kultur er især udbredt hos de midaldrende og de ældre dele af vælgerkorpset. Der er gode grunde til at forvente, at der skal strukturelle faktorer til for at udfordre denne politiske kultur, som på det individuelle plan er ret stabil.

Forskellen er altså markant. De unge er nysgerrige og opmærksomme på valgmuligheder, og de lader sig ikke mindst inspirere, når der er valgkamp. Her overfor finder man den traditionelle politiske kultur, hvor man forsvarer interesser og i forlængelse heraf støtter et bestemt parti, også når der er valg. De unge orienterer sig i forhold til variationen af valgmuligheder og i forhold til, hvordan eksempelvis de politiske ledere begår sig i valgkampen, mens man i den traditionelle kultur orienterer sig i forhold til den løbende magtkamp og det strategiske forsvar for givne interesser.

Partiskift kan med andre ord opfattes som en relativt velintegreret del af de unges politiske kultur. Når det er sagt, skal man imidlertid ikke glemme, at der fortsat er mange unge, der ikke er partiskiftere, ligesom man heller ikke skal glemme, at de unge kun udgør en begrænset del af vælgerkorpset. I det datamateriale, der benyttes her, udgør de 13 pct. af populationen.

\section{Generationer og politisk kultur}

Set i et generationsperspektiv kan man kort sige, at der er tre mønstre på spil her (Andersen, 2001. Rathlev, 2007: 109f). Den traditionelle politiske kultur var baseret på interesser og magtkamp. $\mathrm{Og}$ den kom ikke mindst til udtryk i form af en solid støtte til et bestemt parti, hvis ledere blev opfattet som dem, der stod i spidsen for forsvaret af givne interesser. Det er en kultur, man især finder hos de ældste vælgere i dag. Derfor er der også færrest partiskiftere her.

Med ungdomsoprøret og fremkomsten af 68'er-generationen dukkede en ny politisk kultur op. Denne generations mest aktive og markante dele havde det politiske som et af de fundamentale identitetselementer. Ikke mindst, fordi det omgivende samfund reagerede på ungdomsoprøret og 
kaldte de unge for 'farlige unge'. De unge forsvarede sig mod 'det etablerede', og derfor blev det politiske et naturligt element i deres identitet. Denne generation udviklede nye politiske værdier, hvilket ikke mindst kom til udtryk i form af udviklingen af nye venstreorienterede partier, et udbredt ønske om mere demokrati i samfundet, om ligestilling og en værdsættelse af politisk deltagelse, ikke mindst i græsrodsbevægelser. Man dyrkede altså i princippet det åbne valg mellem de politiske partier, samtidig med at man var dybt forankret i en venstreorienteret kultur. Derfor var denne generation den mest venstreorienterede generation i Danmark, hvilket den stadig er. Generationen åbnede for det individuelle valg som princip, men man har samtidig nogle fundamentale interesser, centreret omkring opgøret med 'det etablerede', som man gerne vil forfølge. Det er værdier og holdninger, der kan genfindes hos denne generation i dag, om end i andre former og med et andet indhold. Denne generation opfatter med andre ord stadig sig selv som et udtryk for en 'alternativ' politisk kultur.

68'erne blev udfordret af punk-kulturen, der ikke gad de mange 68'ere og deres overpædagogiske 'alternative' kultur. Dette brud åbnede vejen for 80'ernes unge, der ikke mindst udviklede en kultur baseret på det modsatte af det, man dyrkede hos 68'erne. Hvor de havde fokuseret på det politiske, lagde 80'er-generationen vægt på det økonomiske. Hvor 68'erne havde dyrket det kollektive, lagde 80'er-generationen vægt på det individuelle. Godt hjulpet på vej af nykonservatismen, der kulturelt, socialt og politisk dominerede store dele af Europa på dette tidspunkt. Derfor var der også en vis logik $i$, at man blev den mest højreorienterede generation i Danmark, hvad man fortsat er. Generationen er altså fanget i en modsætning mellem på den ene side at være individualister, og dermed en gruppe med hang til at skifte parti i ny og næ, og på den anden side en gruppe. der dyrker det højreorienterede. Noget der bl.a. viser sig i form af en ret stor trofasthed overfor partiet Venstre.

Det er bl.a. i dette perspektiv, man skal se nutidens unge og deres tendens til i relativt stor udstrækning at skifte parti ved valgene. For dem udgør det politiske ikke et centralt element i deres identitetsdannelse. Der er ikke nogle bestemte interesser, de skal forsvare, og der er ikke nogle bestemte generationer eller kulturelle udtryk, som de skal lægge afstand til. De dyrker derimod med stor nysgerrighed og opmærksomhed en politisk kultur med fokus på muligheder, tilgængelighed og mangfoldighed. Politisk spreder de sig over hele spektret og har, som det er nævnt ovenfor, ikke de store problemer med at orientere sig i forhold til nye partier og politikere. Set i det lys er spørgsmålet, om man her ser nogle centrale elementer i fremtidens politiske kultur.

\section{Politik som oplevelse eller rationalitet}

Hvis man skal sætte ord på de ovennævnte tendenser i moderne politik, kan man sige, at oplevelsesbaserede elementer trænger sig mere og mere på. At flere og flere vælgere afgør deres politiske præferencer med udgangspunkt i den måde, man oplever det politiske på. Hvilket naturligt nok åbner for eksempelvis partiledernes voksende indflydelse på vælgerne, når de skal afgøre, hvor krydset skal sættes. Det sker på bekostning af eksempelvis viden, dyrkelse af egne interesser og basale socialt funderede holdninger. Hvor det centrale altså er, at det oplevelsesbaserede element cirkler om det umiddelbare, det spontane og det følelsesmæssige, mens det rationelle mere vægter viden, holdninger og strategiske overvejelser om magtrelationer (Andersen, 2004: 130ff; Andersen \& Kristensen, 2006; Hjarvard, 2005: 55f). Der kan selvfølgelig være tale om et resultat af, at flere partier ligner hinanden, $\mathrm{og}$ at de derfor på den måde åbner for partiskift, uden at det făr de store konsekvenser. Men i denne sammenhæng vil jeg gerne holde fast ved antagelsen om, at der er tale om nye basale elementer i den politiske kultur.

$\mathrm{Nu}$ kan man strengt taget ikke sige noget om udviklingsperspektiver, når man kun har et enkelt målepunkt, nemlig folketingsvalget 2005. Andre tidligere valganalyser indeholder ikke oplysninger, der gør det muligt at gå nærmere ind i de ovennævnte sammenhænge. Men netop data fra folketingsvalget 2005 indeholder et par spørgsmål, der illustrativt kan åbne lidt mere for de ovennævnte perspektiver.

Det drejer sig for det første om vælgernes faktiske vidensniveau om politik, og for det andet om deres egen vurdering af, hvorvidt de sætter deres kryds udelukkende med udgangspunkt i politiske holdninger, eller om deres vurdering af de politiske ledere også spiller en vis rolle. Hvilket indirekte også åbner for medieorienterede problemstillinger. For antagelser om partilederes voksende betydning 


\section{Figur 1. Typologi over vælgere med forskelligt vidensniveau og personindflydelse}

\begin{tabular}{|c|c|c|c|}
\hline & \multicolumn{2}{|c|}{ Vidensniveau } \\
\hline & & Lavt & Højt \\
\hline \multirow[t]{2}{*}{$\begin{array}{l}\text { Vælgere sæt- } \\
\text { ter kryds ud } \\
\text { fra: }\end{array}$} & $\begin{array}{l}\text { Politiske } \\
\text { holdninger }\end{array}$ & $\begin{array}{l}\text { De traditionelle } \\
\text { Vælgere med faste politiske } \\
\text { holdninger og et lavt vidensni- } \\
\text { veau om politik. } \\
12 \text { pct. af befolkningen }\end{array}$ & $\begin{array}{l}\text { De politisk aktive } \\
\text { Vælgere med højt vidensniveau } \\
\text { og vægtning af politiske hold- } \\
\text { ninger. } \\
32 \text { pct. af befolkningen }\end{array}$ \\
\hline & $\begin{array}{l}\text { De politiske } \\
\text { ledere spiller } \\
\text { også en rolle }\end{array}$ & $\begin{array}{l}\text { De oplevelsesorienterede } \\
\text { Vælgere med lavt vidensniveau } \\
\text { og under indflydelse af politiske } \\
\text { ledere } \\
22 \text { pct. af befolkningen }\end{array}$ & $\begin{array}{l}\text { De politisk interesserede } \\
\text { Vælgere med højt vidensniveau } \\
\text { og under indflydelse af politiske } \\
\text { ledere. } \\
34 \text { pct. af befolkningen. }\end{array}$ \\
\hline
\end{tabular}

Kilde: Data fra Folketingsvalget 2005, Aalborg Universitet.

er samtidig en antagelse om, at de mediebaserede elementer i politik fylder mere og mere. Ud fra den antagelse, at politiske ledere netop især gør en forskel via medierne.

Ved at bruge de to nævnte spørgsmål er man i stand til at kombinere vidensniveau med det rationelle eller subjektive element. Hvor det rationelle altså er knyttet til stemmeafgivning ud fra holdninger, og det subjektive er knyttet til politiske lederes mulige indflydelse. Sætter man disse to dimensioner sammen, får man en typologi, indeholdende fire interessante positioner. De er angivet i figur 1. Sammenholder man denne typologi med forskellige spørgsmål i valgundersøgelsen, får man et vist indtryk af de forskellige typers sociale baggrund og politiske adfærd. Det er sket i tabel 2.

Overskriften på de fire typer er udarbejdet med henblik på at give en antydning af den politiske kultur, de dækker over. Den første type kaldes de traditionelle, og det er den mindste gruppe. Man ved ikke så meget om politik og lægger vægt på holdninger. Som det fremgår af tabel 2 skiller denne gruppe sig ikke ud fra gennemsnittet rent aldersmæssigt, mens der er overvægt af kvinder. Her er relativt mange partiskiftere, ligesom det er her, man finder den største gruppe, der ved valget i 2005 gik fra et borgerligt til et socialistisk parti (S, SF og Enhedslisten). Gruppen er altså ikke mere traditionel i sit forhold til politik, end at man godt kan skifte parti. Men det sker altså med udgangspunkt i det holdningsmæssige. Noget, man angiveligt danner sig indtryk af især gennem et stort tv-forbrug. Der er også lavet en opgørelse over gruppernes sociale kapital, dvs. deres tillid til andre mennesker. Hos denne gruppe ligger den sociale kapital på det laveste niveau, markant under gennemsnittet. Et forhold, der kan antyde en relativt isoleret gruppe, uden den helt store føling med det politiske og sociale liv.

Den næste type kaldes de oplevelsesorienterede, og den omfatter i denne sammenhæng 22 pct. af vælgerne. Det er en gruppe, der ikke ved så meget om politik, og som efter eget udsagn ikke bare stemmer ud fra politiske holdninger, men som også er under påvirkning af politiske ledere, når krydset skal sættes. Det er derfor, jeg fremhæver oplevelseselementet hos denne gruppe. Aldersmæssigt er de unge og 80'er-generationen overrepræsenteret her, ligesom der også er overvægt af kvinder. Det er her, man finder det største antal partiskiftere og den største andel vælgere, der skifter fra et socialistisk til et borgerligt parti. Der er relativt mange i denne gruppe, der ikke følger med i politik gennem dagligt medieforbrug. Endelig er gruppens sociale kapital relativt lav.

Den tredje type kaldes for de politisk aktive, og den omfatter de vælgere, der både har et højt vidensniveau, og som efter eget udsagn kun fokuserer på 
Tabel 2. Typer af valgere, deres sociale baggrund og politiske adfærd. 2005

\begin{tabular}{|c|c|c|c|c|c|}
\hline & $\begin{array}{c}\text { De } \\
\text { tradi- } \\
\text { tionelle }\end{array}$ & $\begin{array}{c}\text { De } \\
\text { oplevelses- } \\
\text { orienterede }\end{array}$ & $\begin{array}{c}\text { De } \\
\text { politisk } \\
\text { aktive }\end{array}$ & $\begin{array}{c}\text { De politisk } \\
\text { inter- } \\
\text { esserede }\end{array}$ & Total \\
\hline \multicolumn{6}{|l|}{ Køn } \\
\hline Mænd & 46 & 41 & 64 & 58 & 55 \\
\hline Kvinder & 54 & 59 & 36 & 42 & 45 \\
\hline \multicolumn{6}{|c|}{ Generationer - født: } \\
\hline $1975-88$ & 15 & 22 & 7 & 13 & 13 \\
\hline $1960-74$ & 26 & 35 & 21 & 27 & 27 \\
\hline 1945-59 & 30 & 21 & 35 & 27 & 28 \\
\hline $1930-44$ & 20 & 14 & 28 & 23 & 23 \\
\hline før 1930 & 10 & 8 & 10 & 9 & 9 \\
\hline \multicolumn{6}{|c|}{ Interesse i politik } \\
\hline $\begin{array}{l}\text { Meget og noget } \\
\text { interesseret }\end{array}$ & 66 & 48 & 86 & 76 & 72 \\
\hline \multicolumn{6}{|l|}{ Partisympati } \\
\hline $\begin{array}{l}\text { Ikke fast tilhænger } \\
\text { af et parti }\end{array}$ & 45 & 62 & 37 & 58 & 51 \\
\hline Partiskifter & 29 & 30 & 18 & 27 & 25 \\
\hline \multicolumn{6}{|c|}{ Vælgervandringer } \\
\hline $\begin{array}{l}\text { Fra borgerligt } \\
\text { til socialistisk parti }\end{array}$ & 8 & 5 & 2 & 4 & 4 \\
\hline $\begin{array}{l}\text { Fra socialistisk } \\
\text { til borgerligt parti }\end{array}$ & 5 & 7 & 3 & 7 & 5 \\
\hline \multicolumn{6}{|l|}{ Medieforbrug } \\
\hline \multicolumn{6}{|l|}{$\begin{array}{l}\text { - følger dagligt } \\
\text { politik via: }\end{array}$} \\
\hline TV & 59 & 47 & 61 & 55 & 56 \\
\hline Avislæsning & 35 & 34 & 53 & 48 & 45 \\
\hline Internettet & 10 & 10 & 16 & 13 & 13 \\
\hline \multicolumn{6}{|l|}{$\begin{array}{l}\text { Social kapital } \\
\text { - tillid til andre }\end{array}$} \\
\hline $\begin{array}{l}\text { Gns. på skala } \\
\text { fra } 0 \text { til } 3\end{array}$ & 1,45 & 1,62 & 1,91 & 1,88 & 1,78 \\
\hline
\end{tabular}

Kilde: Data fra Folketingsvalget 2005, Aalborg Universitet 
politiske holdninger, når krydset skal sættes. Det er en gruppe med stor interesse for politik, hvilket også viser sig på den måde, at gruppen er blandt de flittigste, når det drejer sig om at gå til vælgermøder. Aldersmæssigt er 68'erne og de ældste overrepræsenterede her, ligesom der også er overrepræsentation af mænd. Gruppen har den største andel af faste partisympatisører, og derfor er det heller ikke så overraskende, at det er her, man finder det laveste antal partiskiftere. Derfor er der også kun få af disse vælgere, der går på tværs af de politiske blokke. Gruppen har det største daglige medieforbrug, når det drejer sig om at følge med i politik. Man er således overrepræsenteret både når det drejer sig om at følge med i tv og i avisen. Gruppens sociale kapital er den højeste blandt de fire grupper.

Endelig er der den fjerde type, som kaldes for de politisk interesserede. Der er nemlig tale om en gruppe med et højt vidensniveau, og efter eget udsagn også en gruppe, hvor politiske ledere spiller en vis rolle, når det skal afgøres, hvor krydset skal sættes. Det er den største gruppe i denne typologi. Aldersmæssigt ligger gruppen tæt på gennemsnittet. Stor interesse for politik, men relativt få med fast partitilhørsforhold. Også her er der relativt mange partiskiftere. Man skal imidlertid huske at tilføje, at partiskifterne også er overrepræsenterede hos de oplevelsesorienterede og de politisk aktive. Hvilket blot understreger, at der kan være andre faktorer end de rent oplevelsesbaserede elementer på spil, når vælgerne finder ud af, hvorvidt de gerne vil stemme på et nyt parti.

Det er vigtigt for mig at slå fast, at den ovennævnte eksemplariske opdeling i et oplevelsesbaseret og et rationelt forhold til det at vælge mellem de politiske partier ikke i udgangspunktet er koblet sammen med bestemte normative positioner. Demokratisk set er det underordnet, om man stemmer med udgangspunkt i gode oplevelser eller gode argumenter. Af flere grunde.

For det første fordi man ikke i det endelige valgresultat kan aflæse, om en stemme er afgivet med udgangspunkt i det ene eller det andet. Demokrati er grundlæggende udformet som en række procedurer, der skal sikre, at alle får medindflydelse på det offentlige liv. Hvad folk har af motiver for at stemme på et parti er demokratisk set lige gyldigt, ikke mindst fordi der kan lokaliseres mange forskellige grunde til at stemme, som man gør. Men procedurerne og det samlede resultat skulle gerne sikre den enkelte medborgers medindflydelse i forhold til det politiske liv (Torpe, 2005: 17ff).

For det andet spiller både følelser og fornuft formodentlig en rolle hos alle vælgere. Også selv om man ikke umiddelbart vil være ved det. Der er i hvert fald meget, der tyder på, at der kan være mange irrationelle elementer på spil, når rationelle beslutninger om politik skal træffes. Både hos politikere og hos vælgere. Følelser og fornuft har det altså med at blande sig i de sociale processer. Dertil kommer, at moderne hjerneforskning har vist, at centrene for følelser og fornuft ligger meget tæt på hinanden. Så tæt, at man arbejder med hypoteser om, at de også af biologiske grunde spiller tæt sammen (Kringelbach, 2006: 170f).

En sådan udvikling kan på sigt sagtens medføre, at manipulation og spin får større og større indflydelse på både politikeres, partiers og vælgeres adfærd, hvilket uden tvivl samtidig kan stimulere en udvikling i retning af endnu mere medieformidlet dramatisering, idet det jo er mediernes mulighed for at optimere antallet af læsere eller lyttere. Med uheldige konsekvenser til følge, hvis det er sådan, at vælgerne ikke er i stand til at overskue det politiske landskab, fordi det hele tiden dynges til af bevidste og ubevidste forsøg på at påvirke vælgeres følelser og samtidig skjule centrale dele af det politiske magtspil (Andersen, 2004; Hjarvard, 2005). Et er nemlig, hvilke motiver vælgerne kan have for at beslutte, hvor de skal sætte deres kryds. Noget andet er, at de under alle omstændigheder skal have åben adgang til alle de muligheder, man kan stemme ud fra. De demokratiske procedurer modarbejdes, når manipulationer og spin fordrejer eller skjuler dele af det politiske landskab.

\section{Kernevælgere, partiskiftere og politikeres selvfremstilling}

Partiskiftere bliver et mere og mere centralt element i den moderne politiske kultur, og som sådan er de medvirkende til at give de politiske processer dynamik og udfordringer. Men nu afgøres valgene ikke alene ved hjælp af partiskiftere. Alle partier skal altid sikre sig, at de som udgangspunkt kan fastholde tilslutningen fra deres kernevælgere. Derfor har de politiske partier altid brug for at kommunikere synspunkter i forhold til vælgerne, der kan bekræfte kernevælgerne, og dermed fastholde deres støtte. Her spiller de politiske lederes evner til at give politikken og de gode argumenter et men- 
neskeligt ansigt formodentlig en vis rolle. Også selv om denne gruppe selv angiver, at den ikke lader sig påvirke af politiske ledere, når man afgiver sin stemme.

Resultatet af ovennævnte tilstand er, at den politiske kommunikation i forbindelse med eksempelvis et folketingsvalg er kendetegnet ved, at man benytter sig af mange forskellige elementer. Både dem, der fokuserer på og fremhæver politiske interesser og argumenter, og dem, der sætter oplevelser i centrum. Den politiske kommunikation indeholder altså både elementer, der fokuserer på argumenter, og elementer, der fokuserer på medieformidlede oplevelser (Jønsson \& Larsen, 2002. Bro et al., 2006). Udfordringen for politikerne bliver derfor at opretholde deres troværdighed over for kernevælgerne, når de forsøger at række ud efter partiskifterne.

Ser man lidt frem i tiden, er der gode grunde til at forvente, at der bliver flere og flere partiskiftere. Derfor er der gode grunde til at være opmærksom på, at denne oplevelsesfundering af politik kræver stærke kritiske modspil og distancer hos vælgerne, hvis ikke politik i almindelighed og valgkampe i særdeleshed skal ende i de rene følelsesbaserede spin-manipulationer. Under alle omstændigheder bliver politikernes medierede selvfremstilling mere og mere central for deres mulighed for at agere $\mathrm{i}$ det politiske landskab.

\section{Referencer}

Andersen, J.1999. “Generationer med egen valgkamp”, i J. Andersen, O. Borre, J. Goul Andersen og H.J. Nielsen. Velgere med omtanke. En analyse af folketingsvalget 1998. Århus. Systime.

Andersen, J. 2000. "Demokratiske normer", i J. Goul Andersen, L. Torpe og J. Andersen. Hvad folket magter. Demokrati, magt og afmagt. København. Jurist- og Økonomforbundets Forlag.

Andersen, J. 2001. Mellem hoved og krop. Om ungdomskulturer. Århus. Systime.

Andersen, J. \& Goul Andersen, 2003. "Køn, alder og uddannelse: De unge mænds sejr", i J. Goul Andersen, J. og O. Borre (red.). Politisk forandring. Vordipolitik og nye skillelinjer ved folketingsvalget 2001. Århus. Systime Academic.

Andersen, J. 2004. Den politiske blender - en moderne leser om politik og demokrati. Århus. Hovedland.
Andersen, J \& N. Nørgaard Kristensen, 2006. "Between Individualism and Community. On Media Consumption, Political Interest and The Public", i Nordicom Review. Nr. 2. 2006.

Andersen, J. 2007. "Politikken der blev væk", i Rason nr. 2. 2006.

Bro et al., 2006. P. Bro, R. Jønsson og O. Larsen (red.). Politisk journalistik og kommunikation. Forandringer $i$ forholdet mellem politik og medier. København. Samfundslitteratur.

Hjarvard, 2005. S. Hjarvard. Det selskabelige samfund. Essays om medier mellem mennesker. København. Samfundslitteratur.

Jønsson \& Larsen, 2002. R. Jønsson \& O. Larsen. Professionel politisk kommunikation. Et studie af 20 dages valgkamp. København. Akademisk.

Kringelbach, 2006. M.L. Kringelbach. Hjernerum. Den folelsesfulde hjerne. København. People’s Press.

Lund, 2006. A.B. Lund. "Domesticating the Simpsons. Four Types of Citizenship in Monitorial Democracy", i MedieKultur, 40, 2006.

Marsen, 2006. S. Marsen. Communication Studies. London. Palgrave.

Meyrowitz, 1985. J. Meyrowitz. No sense of Place. The Impact of Electronic Media on Social Behavior. Oxford. Oxford University Press.

Møller Hansen et al. 2007. K. Møller Hansen, R. Slothuus \& C. de Vreese. "Man har et parti, indtil man finder et nyt: Portræt af vælgeren, som skiftede parti”, i J. Goul Andersen, J. Andersen, O. Borre, K. Møller Hansen og H.J. Nielsen (red.). Det nye politiske landskab. Folketingsvalget 2005 i perspektiv. Århus, Academica.

Nielsen \& Thomsen, 2003. H.J. Nielsen \& S. Risbjerg Thomsen. "Vælgervandringer", i J. Goul Andersen og O. Borre (red.). Politisk forandring. Vordipolitik og nye skillelinjer ved folketingsvalget 2001. Århus. Systime Academic.

Rathlev, 2007. J. Rathlev. "Det nye højre er gammelt: Politiske generationer i perspektiv", i J. Goul Andersen, J. Andersen, O. Borre, K. Møller Hansen og H.J. Nielsen (red.). Det nye politiske landskab. Folketingsvalget 2005 i perspektiv. Århus, Academica.

Schudson, 2006. M. Schudson. "New Technologies and Not-so-new Democracies", i MedieKultur, 40, 2006.

Torpe, 2005. L. Torpe. "Internet, demokrati og politisk offentlighed”, i L. Torpe, J.A. Nielsen og J. Ulrich. Demokrati på nettet. Offentlighed, deltagelse og digital kommunikation. Aalborg. Aalborg Universitetsforlag.

Johannes Andersen er lektor og samfundsforsker ved Aalborg Universitet. Koordinator i Netværket for politisk kommunikation og deltagelse ved Institut for økonomi, politik og forvaltning, Aalborg Universitet. 